\title{
Prognostic Significance of Wnt-1, $\beta$-catenin and E-cadherin Expression in Advanced Colorectal Carcinoma
}

\author{
Aleksandra Stanczak • Rafal Stec • Lubomir Bodnar • Wojciech Olszewski • \\ Marzena Cichowicz • Wojciech Kozlowski • Cezary Szczylik • Tadeusz Pietrucha • \\ Maciej Wieczorek • Monika Lamparska-Przybysz
}

Received: 20 December 2010 / Accepted: 27 April 2011/Published online: 16 June 2011

(C) The Author(s) 2011. This article is published with open access at Springerlink.com

\begin{abstract}
Wnt/ $\beta$-catenin pathway plays an important role in initiation and progression of colorectal oncogenesis. The aim of this study was to determine expression and localization of E-cadherin, $\beta$-catenin and Wnt-1 proteins in colorectal tumors. Expression of $\beta$-catenin, E-cadherin and Wnt-1 was determined by immunohistochemistry on advanced colorectal cancers. Abnormal expression of Ecadherin, $\beta$-catenin, Wnt-1 was observed. Additionally, we revealed correlations between levels of studied proteins and histoclinical data. In multivariate analysis nuclear $\beta$ -
\end{abstract}

A. Stanczak $\cdot$ T. Pietrucha

Department of Medical Biotechnology,

Medical University of Lodz,

Lodz, Poland

A. Stanczak $(\bowtie) \cdot$ M. Wieczorek $\cdot$ M. Lamparska-Przybysz Innovative Drugs Research \& Development Department,

Celon Pharma Ltd.,

41A Mokra St. Kielpin,

05-092 Lomianki, Poland

e-mail: aleksandra.stanczak@celonpharma.com

R. Stec $\cdot$ L. Bodnar $\cdot$ C. Szczylik

Department of Oncology,

Military Institute of the Health Services in Warsaw,

Warsaw, Poland

W. Olszewski

Department of Pathology, Institute of Oncology,

Warsaw, Poland

M. Cichowicz $\cdot$ W. Kozlowski

Department of Pathology,

Military Institute of the Health Services in Warsaw,

Warsaw, Poland catenin, higher carcinoembryonic antigen serum level before treatment, female sex and tumor localized in colon or rectum were independent unfavorable prognostic factors. These findings support the hypothesis that $\mathrm{Wnt} / \beta$-catenin pathway plays an important role in advanced colorectal carcinoma.

Keywords $\beta$-catenin · E-cadherin · Wnt-1 - Wnt signaling pathway $\cdot$ Advanced colorectal carcinoma $\cdot$ Prognostic factor

$\begin{array}{ll}\text { Abbreviations } \\ \text { APC } & \text { Adenomatous polyposis coli } \\ \beta \text { TrCP } & \text { Ubiquitin ligase protein } \\ \text { CTNNB1 } & \text { 3-catenin gene } \\ \text { CDH1 } & \text { E-cadherin gene } \\ \text { CEA } & \text { Carcinoembryonic antigen } \\ \text { CI } & \text { Confidence interval } \\ \text { CKI } & \text { Casein kinase I } \\ \text { CRC } & \text { Colorectal carcinoma } \\ \text { DFS } & \text { Disease free-survival } \\ \text { FAP } & \text { Familial adenomatous polyposis } \\ \text { FOLFIRI } & \text { 5-fluorouracil leucovorin and irinotecan } \\ \text { FOLFOX4 } & \text { 5-fluorouracil leucovorin and oxaliplatin } \\ \text { GSK3 } \beta & \text { Glycogen synthase kinase 3 } \beta \\ \text { K-RAS } & \text { v-Ki-ras2 Kirsten rat sarcoma viral oncogene } \\ & \text { homolog } \\ \text { HR } & \text { Hazard ratio } \\ \text { MMP7 } & \text { Metalloproteinase 7 } \\ \text { OS } & \text { Overall survival } \\ \text { R } & \text { Spearman's rank correlation coefficient } \\ \text { TCF/Lef } & \text { T-cell factor/lymphoid enhancer factor } \\ \text { Wnt-1 } & \text { Wingless-type MMTV integration site family } \\ & \text { member 1 }\end{array}$




\section{Introduction}

Colorectal carcinoma (CRC) is one of the most common human cancers. In 2008, 1233000 new CRC patients were diagnosed worldwide and about 608000 deaths caused by colorectal cancer were estimated making it the fourth most common cause of death from cancer [1]. Five-year survival for CRC patients amounts 54\% in Europe, but in Poland it is lower and amounts $38.8 \%$ [2]. Additionally, observed five-year survival for patients with stage I is $74.0 \%, 66.5 \%$ in patients with stage IIA disease, $73.1 \%$ in patients with stage IIIA disease and only $5.7 \%$ in patients with stage IV disease [3].

There are many factors influencing colorectal cancer prognosis. According to College of American Pathologists fundamental prognostic factors are: extent of tumor (pT category), regional lymph node metastasis ( $\mathrm{pN}$ category), blood or lymphatic vessel invasion, residual tumor following surgery and serum level elevation of carcinoembryonic antigen (CEA) before treatment [4]. Other clinical and pathological factors are also extensively studied, for example histological type or microvessel density $[5,6]$. Moreover, molecular markers are becoming to be important variables that have an impact on CRC patient prognosis. Variety of proteins are extensively explored in colorectal carcinoma.

Particular interest of scientists is focused on a multifunctional protein - $\beta$-catenin. Along with E-cadherin it forms adherent junctions mediating epithelial cell adhesion and it is the key protein in canonical Wnt signaling pathway [7]. In the absence of Wnt ligands, $\beta$-catenin abundantly occurs in adherent complexes, while its level in the cytoplasm is very low. Free cytosolic $\beta$-catenin is phosphorylated in a complex formed by adenomatous polyposis coli (APC), Axin, glycogen synthase kinase $3 \beta$ (GSK3 $\beta$ ) and casein kinase I (CKI). Phosphorylated $\beta$-catenin is ubiquitinated by ubiquitin ligase protein $(\beta \operatorname{TrCP})$ and then degraded in the proteasom. Binding one of the Wnt ligands to the receptors FzD/LRP5/6 triggers signal inactivating the degradation complex. Then $\beta$-catenin is stabilized and goes to the nucleus, where it binds T-cell factor/lymphoid enhancer factor (TCF/Lef) and activates gene expression. Downstream target genes such as cyclin D1 [8], matrix metalloproteinase 7 (MMP7) [9], c-Myc [10], survivin [11] are responsible mainly for cell cycle and proliferation. Therefore, Wnt/ $\beta$-catenin pathway plays an important role in initiation and progression of colorectal carcinoma [12]. Inactivating APC mutations as well as changes in $\beta$-catenin gene $(C T N N B 1)$ often occur in colorectal tumors [13-15]. Additionally, changes of $\beta$-catenin and E-cadherin expression were observed in colorectal carcinoma [16-18].

The aim of this study was to determine the expression and localization of $\beta$-catenin, E-cadherin and Wnt-1 in colorectal tumors and to assess the impact of expression of studied proteins on patients survival.

\section{Material and Methods}

\section{Patients}

Sixty-six unrelated patients with advanced colorectal carcinoma were enrolled consecutively from CRC patients attending Military Institute of the Health Services in Warsaw for palliative care between 2003 and 2008. None of them had a history of familial CRC. All patients were treated according to the routine protocols for CRC patients. All patient underwent radical resection of colorectal cancer while metasectomy was not performed in these group of patients according to guidelines of Polish Society of Clinical Oncology [19]. The study was approved by Local Ethical Committee at the Military Institute of the Health Services, in Warsaw.

Patients characteristic is summarized in Table 1. Out of 66 cases, there were 22 women and 44 men. The mean age was 71 years (range 59-83). Good performance status (WHO $0-2$ or Karnofsky $\geq 80 \%$ ) was displayed by 59 pts $(86.4 \%)$ or 63 pts $(95.5 \%)$, respectively. The majority $(81.8 \%)$ had T3 tumors and 46 pts $(69.7 \%)$ had lymph node involvement. All the patients had metastasis, most of which was to the liver (57.6\%). 25 (37.9\%) patients have been treated with adjuvant chemotherapy. Most of the tumors were adenocarcinomas and they were well or moderately differentiated ( $87.9 \%$ and $80.3 \%$, respectively).

\section{Immunohistochemistry}

Formalin-fixed, paraffin-embedded primary tumors were obtained from all patients. Tissue slides were routinely stained with hematoxylin and eosin. For immunohistochemistry analysis the slides were subjected to antigen retrieval in Target Retrieval Solution, pH 9 (DAKO) with PT Link (DAKO). Tissues were incubated with mouse monoclonal antibody anti- $\beta$-catenin (dilution 1:100, clone $\beta$-Catenin-1, DAKO), mouse monoclonal antibody anti-Ecadherin (dilution 1:100, clone NCH-38, DAKO) or rabbit polyclonal antibody anti-Wnt-1 (dilution 1:100, Thermo Scientific). Negative controls were incubated with mouse or rabbit IgGs (DAKO). Detection was done with EnVision $\mathrm{TM}+$ system (DAKO). The expression was scored by two independent observers who had no knowledge of the clinical data. All membranous, cytoplasmic and nuclear staining were evaluated. Staining was graded into four groups: +++ strong, ++ moderate, + weak, 0 negative. Tumors were regarded as immunopositive if $10 \%$ of tumor cells showed immunoreactivity. 
Table 1 Characteristics of patients $(n=66)$

\begin{tabular}{|c|c|}
\hline Characteristics & $n=66$ \\
\hline \multicolumn{2}{|l|}{ Age, years } \\
\hline Median (range) & $71(59-83)$ \\
\hline \multicolumn{2}{|l|}{ Gender } \\
\hline Female & $22(33.3 \%)$ \\
\hline Male & $44(66.6 \%)$ \\
\hline \multicolumn{2}{|l|}{ WHO performance status before palliative treatment } \\
\hline 0 & $18(27.3 \%)$ \\
\hline 1 & $41(62.1 \%)$ \\
\hline 2 & $5(7.5 \%)$ \\
\hline 3 & $2(3.0 \%)$ \\
\hline \multicolumn{2}{|l|}{ Karnofsky performance status before palliative treatment } \\
\hline $60 \%$ & $1(1.5 \%)$ \\
\hline $70 \%$ & $2(3.0 \%)$ \\
\hline $80 \%$ & $5(7.6 \%)$ \\
\hline $90 \%$ & $43(65.2 \%)$ \\
\hline $100 \%$ & $15(22.7 \%)$ \\
\hline \multicolumn{2}{|l|}{ Histopathological type } \\
\hline Adenocarcionoma & $58(87.9 \%)$ \\
\hline Mucinous adenocarcinoma & $1(1.5 \%)$ \\
\hline Unclassified & $7(10.6 \%)$ \\
\hline Use of adjuvant chemotherapy & $25(37.9 \%)$ \\
\hline Elevated CEA level before palliative treatment $(>5 \mu \mathrm{g} / \mathrm{l})$ & $37(56.1 \%)$ \\
\hline \multicolumn{2}{|l|}{ Histological differentiation } \\
\hline Well/moderately & $53(80.3 \%)$ \\
\hline Poorly/undifferentiated & $13(19.7 \%)$ \\
\hline \multicolumn{2}{|l|}{ Lymph node status } \\
\hline No & $20(30.3 \%)$ \\
\hline N1 & $19(28.8 \%)$ \\
\hline $\mathrm{N} 2$ & $19(28.8 \%)$ \\
\hline N3 & $8(12.1 \%)$ \\
\hline \multicolumn{2}{|l|}{ Primary tumor size } \\
\hline $\mathrm{T} 2$ & $3(4.5 \%)$ \\
\hline $\mathrm{T} 3$ & $54(81.8 \%)$ \\
\hline $\mathrm{T} 4$ & $9(13.6 \%)$ \\
\hline \multicolumn{2}{|l|}{ Primary tumor location } \\
\hline Colon & $23(34.8 \%)$ \\
\hline Sigmoid colon & $24(36.4 \%)$ \\
\hline Rectum & $19(28.8 \%)$ \\
\hline \multicolumn{2}{|l|}{ Location of metastases } \\
\hline Liver & $36(57.6 \%)$ \\
\hline Lungs & $19(28.8 \%)$ \\
\hline Other & $23(34.8 \%)$ \\
\hline \multicolumn{2}{|l|}{ Number of organs involved } \\
\hline 1 & $37(56.1 \%)$ \\
\hline$\geq 2$ & $29(43.9 \%)$ \\
\hline \multicolumn{2}{|l|}{ Palliative chemotherapy first line } \\
\hline Capecitabine & $26(39.4 \%)$ \\
\hline Irinotecan & $5(7.6 \%)$ \\
\hline FOLFIRI & $23(34.8 \%)$ \\
\hline FOLFOX4 & $12(18.2 \%)$ \\
\hline
\end{tabular}

Statistics

A Spearman test for non-parametric variables was used to assess correlation between histoclinical data and expression of studied proteins. Overall survival (OS) was defined as time elapsed between date of diagnosis and date of death or the date of last follow-up. The end point of our analysis was established on August 2008. Median and life tables were computed using the product-limit estimate by the Kaplan and Meier method and the log-rank test was employed to assess the statistical significance, $\mathrm{p}$ values less than 0.05 were considered to indicate statistical significance. Univariate and multivariate proportional-hazards models (Cox) were fitted to the data to determine the importance of recognized explanatory variables. Factors that were significant in univariate analysis and factors that showed a trend towards significance were included in the multivariate model which evaluated factors potentially influencing OS [i.e. age ( $<70$ vs. $>70$ years), T stage, type of histology, and performance status]. Multivariate analyses of overall survival were performed by Cox proportional-hazard regression using the forward stepwise method. Statistical calculation were performed using the STATISTICA for Windows Version 7.0 software.

\section{Results}

Expression of E-cadherin, $\beta$-catenin and Wnt-1 in CRC

Normal tissue was available from 32 (48.5\%) patients. In all normal colonic epithelium E-cadherin and $\beta$-catenin were present in the cell membrane with strong, continuous staining. Adhesion proteins were not present in the cytoplasm nor in the nuclei of normal epithelial cells (Fig. 1 a, b). Wnt-1 was expressed in cytoplasm with strong staining. No other localizations of Wnt-1 were found in normal tissue (Fig. 1c).

In colorectal carcinoma, decreased expression and changes of localization of studied proteins were observed (Table 2, Fig. 1d-f). Declined level of membrane Ecadherin and $\beta$-catenin was observed in $31.8 \%(21 / 66)$ and $22.7 \%(15 / 66)$ of patients, respectively. Abnormal cytoplasmic E-cadherin was detected in $37.9 \%(25 / 66)$ of cases. In comparison to the normal epithelium, aberrant cytoplasmic and nuclear $\beta$-catenin was detected in $51.5 \%$ $(34 / 66)$ and $31.8 \%(21 / 66)$ of patients, respectively. We observed that membrane E-cadherin was preserved in those cells where membrane $\beta$-catenin was present. On the other hand, in cancerous tissue cytoplasmic Ecadherin colocalized with $\beta$-catenin. $60.6 \%$ (40/66) of patients had decreased cytoplasmic Wnt-1 expression, while 26 (39.4\%) patients had tumor cells with normal, strong Wnt-1 staining. 

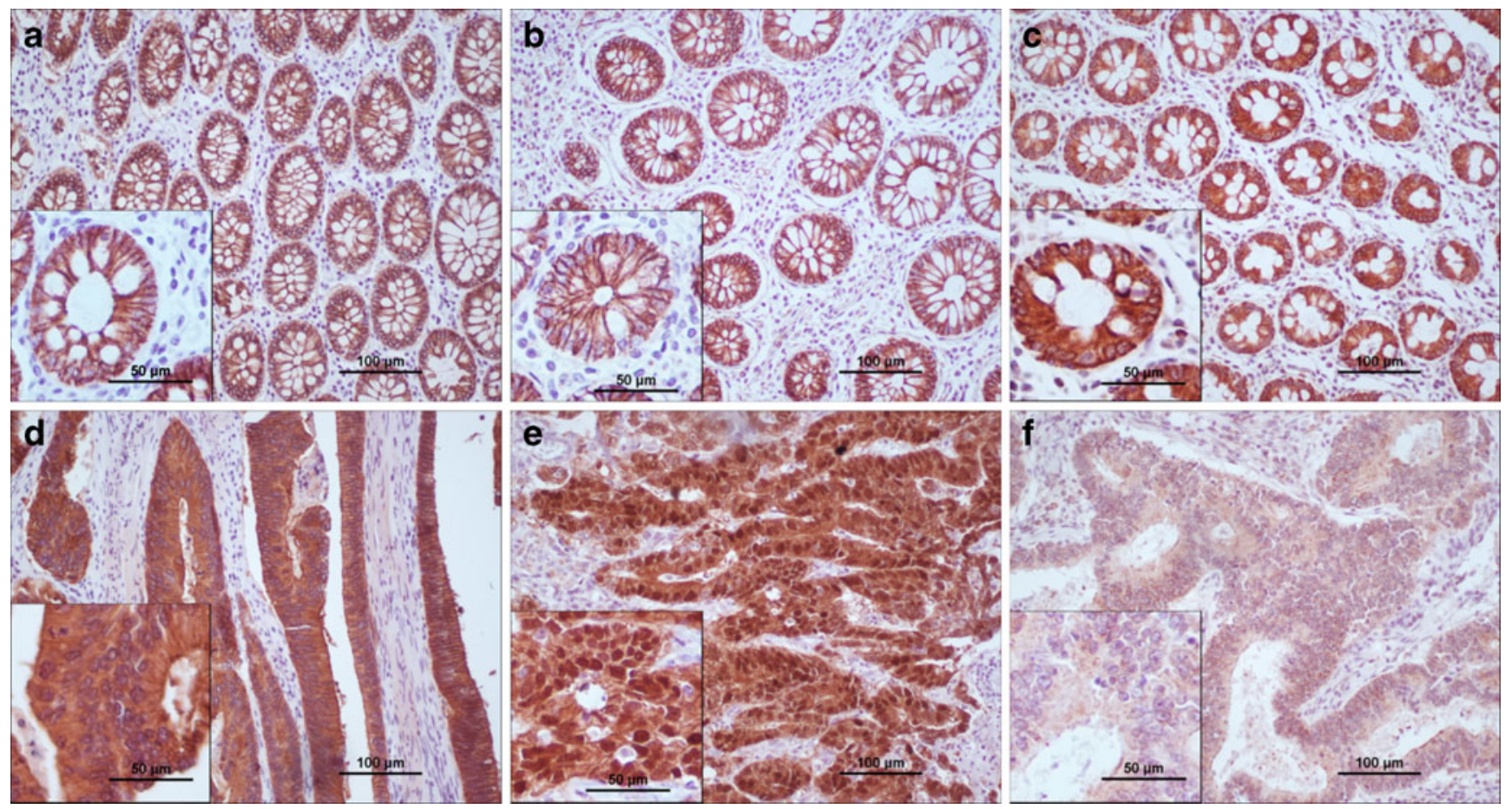

Fig. 1 Expression of E-cadherin, $\beta$-catenin and Wnt-1 in normal colonic epithelium and in colorectal carcinoma. E-cadherin displayed strong membranous immunoreactivity in normal epithelium (a), while in cancer cells decrease of membranous and increase of cytoplasmic E-cadherin was detected (d). High expression of $\beta$-catenin in the cell

\section{Correlation with Histoclinical Data}

Expression of E-cadherin, $\beta$-catenin and Wnt-1 did not significantly correlate with tumor size, lymph node involvement nor histopathological type of tumor. Analysis of histoclinical data and expression of studied proteins revealed association between tumor localization and presence of $\beta$-catenin in nuclei. Cancer localized in rectum displayed greater nuclear localization of $\beta$-catenin than tumors localized in sigmoid and colon ( $\mathrm{R} 0.35 ; p=0.004)$. No other correlation was found.

To investigate the association between expression of studied proteins and survival, log-rank test was performed (Table 3). There were no differences between patient survival and age, sex, performance status, tumor size, lymph node metastasis. As expected, elevated CEA level membrane was found in normal cells (b). Week membranous, moderate cytoplasmic and strong nuclear expression of $\beta$-catenin was observed in tumor tissue (e). In normal epithelial cells high cytoplasmic Wnt-1 expression was detected (c). In colorectal carcinoma, there was weak Wnt-1 immunoreactivity (f)
Table 2 Expression of E-cadherin, $\beta$-catenin and Wnt-1 in colorectal tumors

\begin{tabular}{|c|c|c|c|c|c|c|}
\hline \multirow[t]{2}{*}{ Protein } & \multicolumn{2}{|l|}{ Membrane } & \multicolumn{2}{|l|}{ Cytoplasmic } & \multicolumn{2}{|l|}{ Nuclear } \\
\hline & Normal & Decreased & Present & Absent & Present & Absent \\
\hline E-cadherin & $45(68.2 \%)$ & $21(31.8 \%)$ & $25(37.9 \%)$ & $41(62.1 \%)$ & 0 & 0 \\
\hline$\beta$-catenin & $51(77.3 \%)$ & $15(22.7 \%)$ & $34(51.5 \%)$ & $32(48.5 \%)$ & $21(31.8 \%)$ & $45(68.2 \%)$ \\
\hline Wnt-1 & 0 & 0 & $26(39.4 \%)$ & $40(60.6 \%)$ & 0 & 0 \\
\hline
\end{tabular}

before palliative treatment correlated with shorter survival. Median survival of patients having elevated CEA level was 24.3 months, where median survival of patients having CEA below $5 \mu \mathrm{g} / 1$ was 46.4 months $(p=0.014)$. In addition, patients with tumor localized in colon or rectum had worse prognosis than patients with tumor localized in sigmoid (20.9 vs. 47.9 months, $p=0.028$ ). Among analyzed proteins only nuclear $\beta$-catenin was found to be statistically associated with poor survival. Median survival of patients with colorectal carcinoma displaying nuclear $\beta$-catenin was two times shorter than CRC patients with normal $\beta$-catenin (19.2 vs. 39.8; $p=0.007$ ) (Table 3, Fig. 2).

Factors that were significant in univariate analysis and factors that showed a trend towards significance $(p<0.1)$ were included in the multivariate model which evaluated factors potentially influencing OS (Table 4). We found that, 
Table 3 Univariate analysis of overall survival (log-rank test)

\begin{tabular}{|c|c|c|c|}
\hline Covariate & $n(\%)$ & Median (months) & $\mathrm{p}$ value \\
\hline \multicolumn{4}{|l|}{ Age } \\
\hline$\leq 70$ years & $41(62.1 \%)$ & 31.8 & \multirow[t]{2}{*}{0.741} \\
\hline$>70$ years & $25(37.0 \%)$ & 29.9 & \\
\hline \multicolumn{4}{|l|}{ Gender } \\
\hline Female & $22(33.3 \%)$ & 23.3 & \multirow[t]{2}{*}{0.070} \\
\hline Male & $44(66.7 \%)$ & 35.4 & \\
\hline \multicolumn{4}{|c|}{ Histological differentiation level } \\
\hline Good/average & $53(80.3 \%)$ & 32.6 & \multirow[t]{2}{*}{0.307} \\
\hline Low/unknown & $13(19.7 \%)$ & 16.5 & \\
\hline \multicolumn{4}{|l|}{ Primary location } \\
\hline Sigmoid colon & $25(37.9 \%)$ & 47.9 & \multirow[t]{2}{*}{0.028} \\
\hline Colon/rectum & $41(62.1 \%)$ & 20.9 & \\
\hline \multicolumn{4}{|c|}{ WHO performance status } \\
\hline 0 & $18(27.3 \%)$ & 49.5 & \multirow[t]{2}{*}{0.140} \\
\hline $1-2$ & $48(72.7 \%)$ & 28.1 & \\
\hline \multicolumn{4}{|c|}{ Karnofsky performance status } \\
\hline$\leq 80$ & $8(12.1 \%)$ & 21.4 & \multirow[t]{2}{*}{0.624} \\
\hline$>80$ & $58(67.9 \%)$ & 32.0 & \\
\hline \multicolumn{4}{|c|}{ Primary tumor size } \\
\hline $\mathrm{T} 1-2$ & $3(4.6 \%)$ & NA & \multirow[t]{2}{*}{0.530} \\
\hline $\mathrm{T} 3-4$ & $63(95.4 \%)$ & 31.8 & \\
\hline \multicolumn{4}{|c|}{ Lymph node status } \\
\hline Cancer-free & $20(30.3 \%)$ & 31.5 & \multirow[t]{2}{*}{0.880} \\
\hline Involved & $46(69.7 \%)$ & 30.1 & \\
\hline \multicolumn{4}{|c|}{ Location of metastases } \\
\hline Liver & $38(57.6 \%)$ & 24.7 & \multirow[t]{2}{*}{0.068} \\
\hline Other & $28(42.4 \%)$ & 47.9 & \\
\hline \multicolumn{4}{|c|}{ Number of organs involved } \\
\hline 1 & $37(56.1 \%)$ & 17.2 & \multirow[t]{2}{*}{0.155} \\
\hline$\geq 2$ & $29(43.9 \%)$ & 37.0 & \\
\hline \multicolumn{4}{|c|}{ Pretreatment CEA level $(\mu \mathrm{g} / \mathrm{l})$} \\
\hline$\leq 5$ & $29(43.9 \%)$ & 46.4 & 0.014 \\
\hline$>5$ & $37(56.1 \%)$ & 24.3 & \\
\hline E-cadherin memt & & & \\
\hline normal & $45(68.2 \%)$ & 30.9 & 0.963 \\
\hline decreased & $21(31.8 \%)$ & 32.4 & \\
\hline E-cadherin cytop & & & \\
\hline positive & $25(37.9 \%)$ & 32.7 & 0.952 \\
\hline negative & $41(62.1 \%)$ & 27.6 & \\
\hline$\beta$-catenin membr & & & \\
\hline normal & $51(77.3 \%)$ & 31.7 & 0.649 \\
\hline decreased & $15(22.7 \%)$ & 21.9 & \\
\hline$\beta$-catenin cytopla & & & \\
\hline positive & $34(51.5 \%)$ & 27.4 & 0.707 \\
\hline negative & $32(48.5 \%)$ & 39.9 & \\
\hline$\beta$-catenin nuclear & & & \\
\hline positive & $21(68.2 \%)$ & 19.2 & 0.007 \\
\hline negative & $45(31.8 \%)$ & 39.8 & \\
\hline Wnt-1 & & & \\
\hline normal & $26(39.4 \%)$ & 30.5 & 0.798 \\
\hline decreased & $40(60.6 \%)$ & 30.2 & \\
\hline
\end{tabular}

NA not available

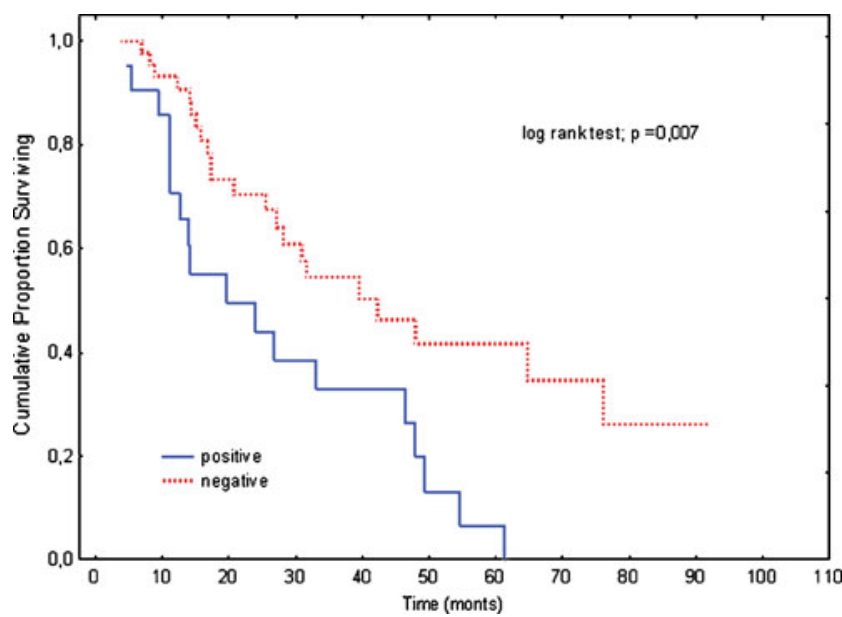

Fig. 2 Overall survival by nuclear $\beta$-catenin expression. The continuous line: nuclear $\beta$-catenin positive $(n=21)$. The dotted line: nuclear $\beta$-catenin negative $(n=45)$. The Kaplan-Meier, log rank test, $p=0.007$

higher CEA serum level before treatment (HR 2.75; 95\% CI 1.15-6.59; $p=0.023$ ), female sex (HR 2.73; 95\% CI $1.32-5.68 ; p=0.023)$ and tumor localized in colon or rectum (HR 3.11; 95\% CI 1.42-6.82; $p=0.005$ ) were independent prognostic factors for shortened survival. Among studied proteins, nuclear $\beta$-catenin was confirmed unfavorable prognostic factor (HR 2.48; 95\% CI 1.30-4.74; $p=0.006)$.

\section{Discussion}

In this study we demonstrated that there are changes in the expression and localization of $\beta$-catenin, E-cadherin and Wnt-1 in advanced colorectal carcinoma. Additionally, we revealed correlations between levels of studied proteins and histoclinical data. We found that nuclear $\beta$-catenin, higher carcinoembryonic antigen serum level before treatment,

Table 4 Multivariate analysis of overall survival

\begin{tabular}{lll}
\hline Covariate & Hazard ratio (95\% CI) & $p$ value \\
\hline $\begin{array}{l}\text { Gender } \\
\quad \text { Female vs. male }\end{array}$ & $2.73(1.32-5.68)$ & 0.007 \\
$\begin{array}{l}\text { Pretreatment CEA level }(\mu \mathrm{g} / \mathrm{l}) \\
\quad>5 \text { vs. } \leq 5\end{array}$ & $2.75(1.15-6.59)$ & 0.023 \\
$\begin{array}{l}\text { Primary location } \\
\quad \text { Colon/rectum vs. sigmoid colon }\end{array}$ & $3.11(1.42-6.82)$ & 0.005 \\
$\begin{array}{l}\text { Nuclear } \beta \text {-catenin } \\
\quad \text { Positive vs. negative }\end{array}$ & $2.48(1.30-4.74)$ & 0.006 \\
\hline
\end{tabular}

Non significant correlations were not shown 
female sex and tumor localized in colon or rectum could be independent unfavorable prognostic factors however the influence of treatment on survival cannot be excluded.

$\beta$-catenin is a protein responsible for cellular adhesion since it forms a complex with E-cadherin. On the other hand, this protein is a key component of Wnt pathway controlling proliferation and cell cycle. Disturbances in both functions of $\beta$-catenin may affect colorectal tumorgenesis. Changes of membrane $\beta$-catenin level may be caused by the decrease of membrane E-cadherin. Our results showing decreased level of membrane $\beta$-catenin and membrane E-cadherin are concordant with numerous earlier reports [16-18, 20, 21]. Additionally, we confirmed previous data concerning detection of E-cadherin in the cytoplasm of tumor cells $[22,23]$. There are few studies documenting that abnormal E-cadherin expression was associated with poor prognosis [20, 22]. However, we did not corroborate those findings.

Genetic alterations, transcriptional changes or protein trafficking could disturb E-cadherin functions. Mutations of $\mathrm{CDH} 1$ encoding E-cadherin are relatively rare in colorectal carcinomas [24, 25], but are more frequent in gastric or breast cancers [26, 27]. Furthermore Truant et al. showed that mRNA level of E-cadherin in colon cancer is not different than in normal tissue [28]. A possible explanation for reduced level of E-cadherin is that proper formation of cell-cell junctions could be disrupted by Src kinase. Elevated Src expression disturbs E-cadherin regulation in colon cancer cells [29]. However, detailed studies focused on control of E-cadherin expression in colorectal carcinoma are needed.

Decreased level of membrane E-cadherin could have an impact on invasiveness of CRC cells. Tumor cell release as a result of disruption of adherent junctions plays a crucial role in metastasis. Expression of Ecadherin observed in metastases varies. Some studies showed that level of E-cadherin decreased in metastatic liver as compared to primary tumor [21]. On the other hand, expression of E-cadherin increased in metastatic lymph nodes compared to primary tumor [30].

Furthermore, we detected $\beta$-catenin in cytoplasm and nuclei of tumor cells. Recent studies showed that, in advanced CRC, there was an increase of cellular and nuclear level of $\beta$-catenin $[16,21,31,32]$. Stabilization of $\beta$-catenin in the cytoplasm, its transport to the nucleus and activation of gene expression is enabled by Wingless pathway. Wnt-1 is one of the ligands which trigger signaling cascade. There are a few inconsistent studies concerning Wnt-1 expression in colon, showing overexpression or lack of expression of Wnt-1 in tumor when compared to the normal colonic mucosa [33-35]. In our study, we showed that in normal colon epithelium there is a high expression of this ligand, whereas in the tumor tissues there was a decrease of Wnt-1 expression. This result suggests other mechanism of $\beta$-catenin accumulation than Wnt-1 activation in analyzed cases of CRC.

Another plausible explanation of $\beta$-catenin stabilization is occurrence of inactivating APC mutations. Most colorectal carcinomas harbor mutations in $A P C$ or $C T N N B 1$ encoding $\beta$-catenin [13-15]. Inactivating mutations in $A P C$ was found in familial adenomatous polyposis (FAP) $[36,37]$, but they also occur in the sporadic CRC $[37,38]$. The most frequent are the mutations in $\beta$-catenin binding domain [39]. Truncated APC is not able to bind the $\beta$-catenin and leads to its accumulation which provokes the activation of downstream target genes [15]. CTNNB1 mutations occur in the region coding amino acids phosphorylated by GSK3 $\beta$ [14]. Thus mutated $\beta$ catenin is rescued from phosphorylation and accumulates in the nucleus.

We observed correlation between nuclear $\beta$-catenin and tumors localized in rectal area. The association between $\beta$ catenin and histoclinical data is disputed subject. There are few inconsistent studies concerning correlation of nuclear $\beta$-catenin with tumor localization. Our results differ from those reported by other groups showing lack of association between tumor localization and presence of nuclear $\beta$ catenin in tumor cells $[40,41]$. Instead we corroborate previous observations that cancer localized in rectum display higher level of nuclear $\beta$-catenin than tumors localized in sigmoid and colon $[42,43]$.

Our search for prognostic factors for CRC resulted in identification of tumor localization as unfavorable prognostic factor. We found that tumors localized in colon or rectum are associated with shorter survival, while tumors localized in sigmoid area are correlated with prolonged survival. Our results are concordant with Wray et al. who performed the study on a large patient cohort (82926 colon cancer cases) and found an association between sigmoid tumors location and decreased colorectal cancer-specific mortality, what is in agreement with our study [44].

Another adverse prognostic factor for CRC identified in our study was the presence of nuclear $\beta$-catenin. Although some reports of nuclear $\beta$-catenin being a favorable

Table 5 Tumor location and nuclear $\beta$-catenin connection

Presence of nuclear $\beta$-catenin

\begin{tabular}{lll}
\hline Tumor location & $\begin{array}{l}\text { Correlation } \\
\text { (R Spearman } \\
\text { test; p value) }\end{array}$ & $\begin{array}{l}\text { Multivariate analysis } \\
\text { Hazard ratio } \\
(95 \% \mathrm{CI}) ; \mathrm{p} \text { value }\end{array}$ \\
\hline $\begin{array}{l}\text { Rectum } \\
\begin{array}{l}\text { Colon } \\
\text { Sigmoid }\end{array}\end{array}$ & $\begin{array}{l}0.35 ; 0.004 \\
\text { NS }\end{array}$ & $3.11(1.42-6.82) ; 0.005$ \\
\hline
\end{tabular}

NS non significant 
predictor of disease free survival (DFS) exist [32], our finding is in agreement with a large body of previously published evidence $[17,22,30]$. Such a discrepancy may result from different localizations of tumors analyzed in particular studies. We found that a high level of nuclear $\beta$ catenin in tumors localized in rectum was paralleled by poor clinical prognosis and that a low level of $\beta$-catenin in nuclei was accompanied by prolonged survival in cases of tumors localized in sigmoid but not in colon (Table 5). These findings suggests that nuclear $\beta$-catenin could be an adverse prognostic factor only for some tumor localization. Moreover, low nuclear $\beta$-catenin level coincides with poor clinical prognosis in patients with cancer localized in colon what suggests existence of additional, yet unidentified factors influencing survival.

The variety of physiological, anatomical and genetic features of distinct sites of a large bowel results in different tumor characteristics dependent on its localization. All of these may influence clinical outcome. The existence of two biologically distinct types of CRC - according to the tumor location in the proximal or distal parts of a large bowel was proposed for the first time by Bufill [45]. In turn, Li et al. suggested that there are three biological types of CRC dependent on tumor localization in proximal colon, distal colon and rectum [46]. Among genetic factors observed in rectal cancers are: high incidence of chromosomal instability, Wnt/ $\beta$-catenin activation and high $\mathrm{p} 53$ expression $[47,48]$. Conversely, microsatellite instability abundance and K-RAS mutations are associated with colon tumors $[47,48]$. Diversity of molecular features of different CRC types results in a complex array of possible prognostic factors for colorectal tumors.

In our study, results of gender analysis may suggest female sex as the unfavorable prognostic factor in colon cancer. However, this observation is in conflict with other reports showing no association between survival and female sex [17, 32, 49]. Cautious interpretation of sex as a prognostic factor in our study is required due to the lack of sex-matched group and relatively small number of patients analyzed.

In analyzed cases, higher CEA serum level before treatment was associated with shorter survival what is in agreement with observation that CEA is elevated in many disorders, particularly in cancers including the colon, rectum, breast and lung [50]. In the management of colorectal carcinoma, CEA level is the most useful clinical marker [50] and assessment of CEA concentration serves as a screening test for CRC [51].

Numerous new markers for colorectal cancer are discovered. Detailed list of factors measured in serum, tissue or stool are described elsewhere [52]. Despite a variety of analysis, there are only few prognostic factors for advanced colorectal carcinoma [4]. For better CRC management more markers are needed. Although molecular markers become more and more important in cancer therapy, additional studies are needed to confirm their usefulness.

\section{Conclusion}

In summary, our study demonstrated that in advanced CRC there are disturbances in expression and localization of $\beta$ catenin, E-cadherin and Wnt-1. We showed the link between tumor localization and pattern of $\beta$-catenin expression and additionally we reveled an association between tumor localization and patient outcome. These finding suggests that nuclear $\beta$-catenin could be an adverse prognostic factor only for some tumor localization. A limitation in our study was the number of patients and controls included. Further investigations on a larger population are needed. These finding support the hypothesis that $\mathrm{Wnt} / \beta$-catenin pathway plays an important role in advanced colorectal carcinoma.

Acknowledgements The work was supported by an internal grant from the Military Institute of the Health Services in Warsaw, Poland and by Celon Pharma Ltd.

We are grateful to Lukasz Bojarski for help with the manuscript.

Open Access This article is distributed under the terms of the Creative Commons Attribution Noncommercial License which permits any noncommercial use, distribution, and reproduction in any medium, provided the original author(s) and source are credited.

\section{References}

1. Ferlay J, Shin HR, Bray F, Forman D, Mathers C, Parkin DM (2010) GLOBOCAN 2008, Cancer Incidence and Mortality Worldwide: IARC CancerBase No. 10. Lyon, France: International Agency for Research on Cancer. http://globocan.iarc.fr. Cited 20 Sept 2010

2. Sant M, Allemani C, Santaquilani M, Knijn A, Marchesi F, Capocaccia R (2009) EUROCARE Working Group. EUROCARE-4. Survival of cancer patients diagnosed in 1995-1999. Results and commentary. Eur J Cancer 45:931-91

3. American Joint Committee on Cancer (2010) Colon and rectum. In: Edge SB, Byrd DR, Compton CC, Fritz AG, Greene FL, Trotti A (eds) AJCC Cancer Staging Manual, The Seventh Edition. Springer, New York

4. Compton CC, Fielding LP, Burgart LJ, Conley B, Cooper HS, Hamilton SR et al (2000) Prognostic factors in colorectal cancer. College of American Pathologists Consensus Statement 1999. Arch Pathol Lab Med 124:979-94

5. Chen JS, Hsieh PS, Chiang JM, Yeh CY, Tsai WS, Tang R et al (2010) Clinical outcome of signet ring cell carcinoma and mucinous adenocarcinoma of the colon. Chang Gung Med J 33:51-7

6. Matsumoto K, Nakayama Y, Inoue Y, Minagawa N, Katsuki T, Shibao K et al (2007) Lymphatic microvessel density is an independent prognostic factor in colorectal cancer. Dis Colon Rectum 50:308-14 
7. MacDonald BT, Tamai K, He X (2009) Wnt/beta-catenin signaling: components, mechanisms, and diseases. Dev Cell 17:9-26

8. Tetsu O, McCormick F (1999) Beta-catenin regulates expression of cyclin D1 in colon carcinoma cells. Nature 398:422-6

9. Brabletz T, Jung A, Dag S, Hlubek F, Kirchner T (1999) beta-catenin regulates the expression of the matrix metalloproteinase-7 in human colorectal cancer. Am J Pathol 155:1033-8

10. He TC, Sparks AB, Rago C, Hermeking H, Zawel L, da Costa LT et al (1998) Identification of c-MYC as a target of the APC pathway. Science 281:1509-12

11. Zhang T, Otevrel T, Gao Z, Gao Z, Ehrlich SM, Fields JZ et al (2001) Evidence that APC regulates survivin expression: a possible mechanism contributing to the stem cell origin of colon cancer. Cancer Res 61:8664-7

12. Gavert N, Ben-Ze'ev A (2007) beta-Catenin signaling in biological control and cancer. J Cell Biochem 102:820-8

13. Powell SM, Zilz N, Beazer-Barclay Y, Bryan TM, Hamilton SR, Thibodeau SN et al (1992) APC mutations occur early during colorectal tumorigenesis. Nature 359:235-7

14. Sparks AB, Morin PJ, Vogelstein B, Kinzler KW (1998) Mutational analysis of the APC/beta-catenin/Tcf pathway in colorectal cancer. Cancer Res 58:1130-4

15. Morin PJ, Sparks AB, Korinek V, Barker N, Clevers H, Vogelstein B et al (1997) Activation of beta-catenin-Tcf signaling in colon cancer by mutations in beta-catenin or APC. Science 275:1787-90

16. Hugh TJ, Dillon SA, O'Dowd G, Getty B, Pignatelli M, Poston GJ et al (1999) beta-catenin expression in primary and metastatic colorectal carcinoma. Int J Cancer 82:504-11

17. Hugh TJ, Dillon SA, Taylor BA, Pignatelli M, Poston GJ, Kinsella AR (1999) Cadherin-catenin expression in primary colorectal cancer: a survival analysis. Br J Cancer 80:1046-51

18. Han SA, Chun H, Park CM, Kang SJ, Kim SH, Sohn D et al (2006) Prognostic significance of beta-catenin in colorectal cancer with liver metastasis. Clin Oncol (R Coll Radiol) 18:761-7

19. Krzakowski M (ed) (2001) Onkologia kliniczna, 1st edn. Warsaw, Borgis Wydawnictwo Medyczne

20. Delektorskaya VV, Perevoshchikov AG, Golovkov DA, Kushlinskii NE (2005) Expression of E-cadherin, beta-catenin, and CD-44v6 cell adhesion molecules in primary tumors and metastases of colorectal adenocarcinoma. Bull Exp Biol Med 139:706-10

21. Choi HN, Kim KR, Lee JH, Park HS, Jang KY, Chung MJ et al (2009) Serum response factor enhances liver metastasis of colorectal carcinoma via alteration of the E-cadherin/beta-catenin complex. Oncol Rep 21:57-63

22. Filiz AI, Senol Z, Sucullu I, Kurt Y, Demirbas S, Levhi Akin M (2010) The survival effect of E-cadherin and catenins in colorectal carcinomas. Colorectal Dis 12:1223-30

23. El-Bahrawy MA, Poulsom R, Jeffery R, Talbot I, Alison MR (2001) The expression of E-cadherin and catenins in sporadic colorectal carcinoma. Hum Pathol 32:1216-24

24. Schuhmacher C, Becker I, Oswald S, Atkinson MJ, Nekarda H, Becker KF et al (1999) Loss of immunohistochemical E-cadherin expression in colon cancer is not due to structural gene alterations. Virchows Arch 434:489-95

25. Hahn-Strömberg V, Edvardsson H, Bodin L, Franzén L (2008) Disturbed expression of E-cadherin, beta-catenin and tight junction proteins in colon carcinoma is unrelated to growth pattern and genetic polymorphisms. APMIS 116:253-62

26. Huiping C, Sigurgeirsdottir JR, Jonasson JG, Eiriksdottir G, Johannsdottir JT, Egilsson V et al (1999) Chromosome alterations and E-cadherin gene mutations in human lobular breast cancer. $\mathrm{Br}$ J Cancer 81:1103-10

27. Huiping C, Kristjansdottir S, Jonasson JG, Magnusson J, Egilsson V, Ingvarsson S (2001) Alterations of E-cadherin and beta-catenin in gastric cancer. BMC Cancer 1:16
28. Truant SC, Gouyer VP, Leteurtre EA, Zerimech F, Huet GM, Pruvot FR (2008) E-cadherin and beta-catenin mRNA levels throughout colon cancer progression. J Surg Res 150:212-8

29. Avizienyte E, Wyke AW, Jones RJ, McLean GW, Westhoff MA, Brunton VG et al (2002) Src-induced de-regulation of E-cadherin in colon cancer cells requires integrin signalling. Nat Cell Biol $4: 632-8$

30. Ikeguchi M, Makino M, Kaibara N (2001) Clinical significance of E-cadherin-catenin complex expression in metastatic foci of colorectal carcinoma. J Surg Oncol 77:201-7

31. Miyamoto S, Endoh Y, Hasebe T, Ishii G, Kodama K, Goya M et al (2004) Nuclear beta-catenin accumulation as a prognostic factor in Dukes' D human colorectal cancers. Oncol Rep $12: 245-51$

32. Elzagheid A, Buhmeida A, Korkeila E, Collan Y, Syrjanen K, Pyrhonen S (2008) Nuclear beta-catenin expression as a prognostic factor in advanced colorectal carcinoma. World J Gastroenterol 14:3866-71

33. Vider BZ, Zimber A, Chastre E, Prevot S, Gespach C, Estlein D et al (1996) Evidence for the involvement of the Wnt 2 gene in human colorectal cancer. Oncogene 12:153-8

34. Holcombe RF, Marsh JL, Waterman ML, Lin F, Milovanovic T, Truong T (2002) Expression of Wnt ligands and Frizzled receptors in colonic mucosa and in colon carcinoma. Mol Pathol 55:220-6

35. Khor TO, Gul YA, Ithnin H, Seow HF (2006) A comparative study of the expression of Wnt-1, WISP-1, survivin and cyclin-D1 in colorectal carcinoma. Int J Colorectal Dis 21:291-300

36. Nishisho I, Nakamura Y, Miyoshi Y, Miki Y, Ando H, Horii A et al (1991) Mutations of chromosome 5q21 genes in FAP and colorectal cancer patients. Science 253:665-669

37. Nakamura Y, Nishisho I, Kinzler KW, Vogelstein B, Miyoshi Y, Miki Y et al (1992) Mutations of the APC (adenomatous polyposis coli) gene in FAP (familial polyposis coli) patients and in sporadic colorectal tumors. Tohoku J Exp Med 168:141-7

38. Varesco L, Gismondi V, James R, Robertson M, Grammatico P, Groden $\mathrm{J}$ et al (1993) Identification of APC gene mutations in Italian adenomatous polyposis coli patients by PCR-SSCP analysis. Am J Hum Genet 52:280-5

39. Polakis P, Hart M, Rubinfeld B (1999) Defects in the regulation of beta-catenin in colorectal cancer. Adv Exp Med Biol 470:23-32

40. Joo M, Shahsafaei A, Odze RD (2009) Paneth cell differentiation in colonic epithelial neoplasms: evidence for the role of the Apc/ beta-catenin/Tcf pathway. Hum Pathol 40:872-80

41. Chiang JM, Chou YH, Chen TC, Ng KF, Lin JL (2002) Nuclear beta-catenin expression is closely related to ulcerative growth of colorectal carcinoma. Br J Cancer 86:1124-9

42. Kapiteijn E, Liefers GJ, Los LC, Kranenbarg EK, Hermans J, Tollenaar RA et al (2001) Mechanisms of oncogenesis in colon versus rectal cancer. J Pathol 195:171-8

43. Aamodt R, Bondi J, Andersen SN, Bukholm G, Bukholm IRK (2008) Expression of nuclear $\beta$-Catenin in rectal versus colonic cancers. Open Clin Cancer J 2:13-17

44. Wray CM, Ziogas A, Hinojosa MW, Le H, Stamos MJ, Zell JA (2009) Tumor subsite location within the colon is prognostic for survival after colon cancer diagnosis. Dis Colon Rectum 52:1359-66

45. Bufill JA (1990) Colorectal cancer: evidence for distinct genetic categories based on proximal or distal tumor location. Ann Intern Med 113:779-88

46. Li FY, Lai MD (2009) Colorectal cancer, one entity or three. J Zhejiang Univ Sci B 10:219-29

47. Nilbert M, Planck M, Fernebro E, Borg A, Johnson A (1999) Microsatellite instability is rare in rectal carcinomas and signifies hereditary cancer. Eur J Cancer 35:942-5 
48. Frattini M, Balestra D, Suardi S, Oggionni M, Alberici P, Radice P et al (2004) Different genetic features associated with colon and rectal carcinogenesis. Clin Cancer Res 10:4015-21

49. Horst D, Reu S, Kriegl L, Engel J, Kirchner T, Jung A (2009) The intratumoral distribution of nuclear beta-catenin is a prognostic marker in colon cancer. Cancer 115:2063-70

50. Mulcahy MF, Benson AB 3rd (1999) The role of carcinoembryonic antigen monitoring in management of colorectal cancer. Curr Oncol Rep 1:168-72
51. Bast RC Jr, Ravdin P, Hayes DF, Bates S, Fritsche H Jr, Jessup JM et al (2001) 2000 update of recommendations for the use of tumor markers in breast and colorectal cancer: clinical practice guidelines of the American Society of Clinical Oncology. J Clin Oncol 19:1865-78

52. Duffy MJ, van Dalen A, Haglund C, Hansson L, Holinski-Feder E, Klapdor R et al (2007) Tumour markers in colorectal cancer: European Group on Tumour Markers (EGTM) guidelines for clinical use. Eur J Cancer 43:1348-60 